\title{
Design Analysis of Overhead Crane for Maintenance Workshop
}

\author{
Siva Sitthipong ${ }^{1, a}$, Chaiyoot Meengam ${ }^{2}$ Suppachai Chainarong $^{2}$ and Prawit Towatana ${ }^{3}$ \\ ${ }^{1}$ Physical Testing Laboratory, Thailand Institute of Scientific and Technological Research, Samut Prakan, Thailand \\ ${ }^{2}$ Faculty of Industrial Technology, Songkla Rajabhat University, Songkhla, Thailand \\ ${ }^{3}$ Marine and Coastal Resources Institute, Prince of Songkla University, Songkhla, Thailand
}

\begin{abstract}
This research aimed to study the design of the overhead crane of a small fishing boat maintenance factory according to the building and functional requirements of the project based on the ASME B30.2-2005 Standard. The results of the study showed that the design of the runway with steel structure BS: 5950: 2000 grade s460 provided vertical and horizontal deflection values of 4.96 and 16.62 respectively that did not exceed the allowed deflection. It is strong enough for use in construction when the stresses on the beam bridge were analysed by the finite element program compared with the strength of the reinforced steel providing a safety value of 1.83 .
\end{abstract}

\section{Introduction}

Utilization of the maintenance buildings possesses specification for the overhead crane which has less than 600 square meters in size, 20 meter wide bridge beam and 30 meter running distance as shown in Fig 1. The height of the crane to the floor does not exceed. 15 meters and the crane must be able to carry a load of 20 tons and the design must comply with the requirements. The structure must be strong, stable, and cost-effective.

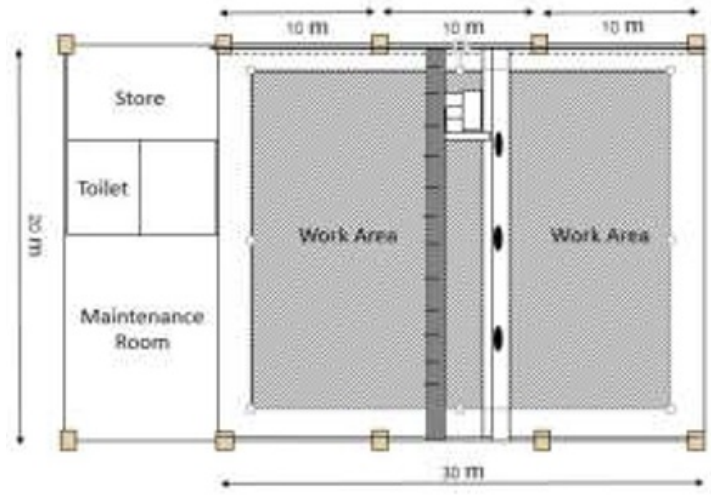

Fig. 1: Install Area of Overhead Crane

\section{Crane Design Method}

\subsection{Design Guidelines}

The main structure of the crane is iron with BS: 5950: 2000 grade S460 and has high strength per weight unit. The design is in accordance with ASME B30.2-2005. The figure is shown in Figure 2. The primary data required for

\footnotetext{
a Corresponding author: siva@tistr.or.th
}

the design calculation is shown in Table 1., requirements. The structure must be strong, stable, and cost-effective.

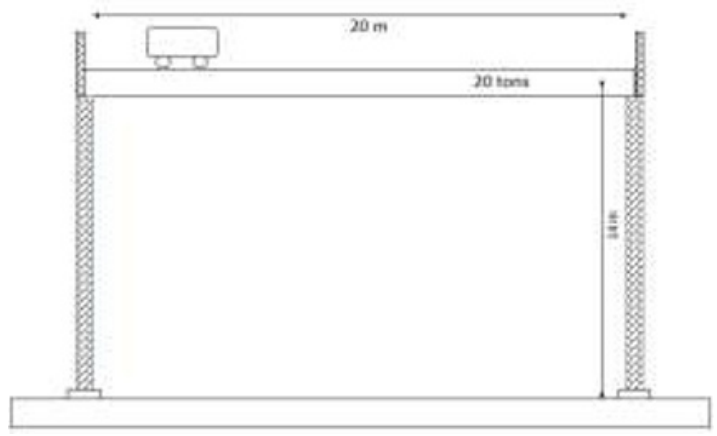

Fig. 2: Overhead Crane

Table 1. Primary data designated in the design

\begin{tabular}{|l|c|c|}
\hline \multicolumn{1}{|c|}{ Parameters } & Symbol & Value \\
\hline Crane Capacity & $\mathrm{W}_{\text {cap }}$ & $200 \mathrm{kN}$ \\
\hline $\begin{array}{l}\text { Weight of Crane Bridge and End } \\
\text { Carriages }\end{array}$ & $\mathrm{W}_{\mathrm{c}}$ & $122 \mathrm{kN}$ \\
\hline Weight of Crab & $\mathrm{W}_{\mathrm{cb}}$ & $15.6 \mathrm{kN}$ \\
\hline $\begin{array}{l}\text { Span } \\
\text { Beetween Crane Rails }\end{array}$ & $\mathrm{L}_{\mathrm{c}}$ & $20 \mathrm{~m}$ \\
\hline $\begin{array}{l}\text { Minimum } \\
\text { Hook Approach }\end{array}$ & $\mathrm{ah}$ & $0.92 \mathrm{~m}$ \\
\hline $\begin{array}{l}\text { Wheel Centres } \\
\text { in End Carriages }\end{array}$ & $\mathrm{s}$ & $4 \mathrm{~m}$ \\
\hline No. of Wheel Flanges & - & 2 \\
\hline Height of Rail & $\mathrm{HR}$ & $50 \mathrm{~mm}$ \\
\hline Span of Crane Girder & $\mathrm{L}$ & $10 \mathrm{~m}$ \\
\hline Self Weight of Crane Girder & $\mathrm{W}_{\mathrm{g}}$ & $12 \mathrm{kN}$ \\
\hline Stiff Bearing Length & $\mathrm{b} 1$ & $150 \mathrm{~mm}$ \\
\hline Beam end to Stiff Bearing Edge & be & $150 \mathrm{~mm}$ \\
\hline $\begin{array}{l}\text { Flange Restrains } \\
\text { For Position and Direction }\end{array}$ & -- & 1 \\
\hline Design Strength & $\mathrm{P}$ & $440 \mathrm{~N} / \mathrm{mm}$ \\
\hline Specific Thickness & $\mathrm{t}$ & $20.2 \mathrm{~mm}$ \\
\hline
\end{tabular}




\subsection{Runway Deflection Analysis}

The vertical and horizontal actual deflection was calculated from (1) and (2), respectively, which was acceptable only if the result was no more than the permitted deflection as calculated from equation (3)

Vertical Actual Deflection $=$ Wus $\mathrm{L}^{\wedge} 3[3(\mathrm{a}+\mathrm{c}) / \mathrm{L}-$ $\left.4\left(a^{\wedge} 3+c^{\wedge} 3\right) / L^{\wedge} 3\right] /[48 E$ Ix $]$

Horizontal Actual Deflection $=$ FR L^3/(48E Iyfc)

Permitted Deflection $=$ Span $/ 600$

The design of the beam cross-section used for deflection analysis is as follows:

The figure is shown in Fig. 3:

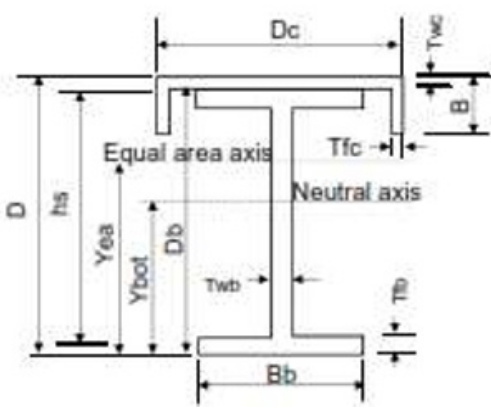

Fig. 3: Overhead Crane.
Table 2. Main Section

\begin{tabular}{c|c}
\hline Mass & 200.9 \\
\hline $\mathrm{Ab} \mathrm{cm}^{2}$ & 256 \\
\hline $\mathrm{Db} \mathrm{mm}$ & 903 \\
\hline $\mathrm{Bb} \mathrm{mm}$ & 303.3 \\
\hline $\mathrm{Tfb} \mathrm{mm}$ & 20.2 \\
\hline $\mathrm{Twb} \mathrm{mm}$ & 15.1 \\
\hline $1 \mathrm{xb} \mathrm{cm} \mathrm{cm}^{4}$ & 325254 \\
\hline $\mathrm{lyb} \mathrm{cm}$ & 9423 \\
\hline $\mathrm{Jb} \mathrm{cm}^{4}$ & 291 \\
\hline $\mathrm{r} \mathrm{mm}$ & 19.1 \\
\hline $\mathrm{d} \mathrm{mm}$ & 824.4
\end{tabular}

Table 3. Top Section

\begin{tabular}{l|c}
\hline Mass kg/m & 67.510 \\
\hline Ac cm & 86 \\
\hline Dc mm & 430 \\
\hline Bc,DL mm & 20 \\
\hline Tfc mm & 0 \\
\hline Twc cm & 20 \\
\hline lxc cm & 13251.167 \\
\hline lyc cm & 28.667 \\
\hline Jc cm & 114.667 \\
\hline Cy cm & 1 \\
\hline
\end{tabular}

Table 4. Forming a Compound Crane Girder Section.

\begin{tabular}{|c|c|c|c|c|c|c|c|c|c|c|}
\hline $\begin{array}{c}M \\
\mathrm{~kg} / \mathrm{m}\end{array}$ & $\mathrm{A} \mathrm{cm}^{2}$ & D mm & B mm & $\begin{array}{l}\text { Ytop } \\
\text { mm }\end{array}$ & $\begin{array}{l}\text { Ybot } \\
\text { mm }\end{array}$ & Ix $\mathrm{cm}^{4}$ & Iy $\mathrm{cm}^{4}$ & $\begin{array}{l}\text { lyfc } \\
\mathrm{cm}^{4}\end{array}$ & $\begin{array}{l}\text { lyft } \\
\mathrm{cm}^{4}\end{array}$ & ry cm \\
\hline 268.410 & 342.000 & 923.000 & 430.000 & 355.450 & 567.550 & 462388 & 22674 & 13251 & 4697 & 8.142 \\
\hline $\begin{array}{c}\text { Zx top } \\
\mathrm{cm}^{3}\end{array}$ & Zxbot $\mathrm{cm}^{3}$ & $\begin{array}{c}\text { Zyfc } \\
\mathrm{cm}^{3}\end{array}$ & $\mathrm{Sx} \mathrm{cm}^{3}$ & $J \mathbf{c m}^{4}$ & hs cm & X const & $\begin{array}{l}\mathrm{DL} \\
\mathrm{mm}\end{array}$ & sai & $\begin{array}{c}\mathrm{N} \\
\text { ratio }\end{array}$ & \\
\hline 13009 & 8147 & 616 & 10962 & 405.667 & 89.280 & 46.398 & 20.000 & 0.385 & 0.738 & \\
\hline
\end{tabular}

Table 5. Equivalent Area Axis \& Plastic Modulus of the Combined Section.

\begin{tabular}{|c|c|c|c|c|c|c|c|}
\hline strip & Width & Height & $y=0$ & Area & Dist comp & Dist ten & Area comp \\
\hline A1 & 430 & 20 & $Y=20$ & 8600 & 20 & 0 & 8600 \\
\hline $\mathrm{A} 2$ & 303.3 & 20.2 & $Y=40.2$ & 812.66 & 20.2 & 0 & 6126.66 \\
\hline A3 & 15.1 & 0 & $Y=40.2$ & 0 & 0.0000 & 0.0000 & 0 \\
\hline A4 & 15.1 & 862.6 & $Y=902.8$ & 13025.26 & 146.5317881 & 716.0682119 & 221263 \\
\hline \multirow[t]{2}{*}{ A5 } & 303.3 & 20.2 & $Y=923$ & 6126.66 & 0 & 20.2 & 0 \\
\hline & & 923 & & 33878.58 & & 923 & 16939.29 \\
\hline Area ten & yc top & yt top & $S x \mathrm{~cm}^{3}$ & & & & \\
\hline 0 & 10.000 & 186.732 & -86.000 & & & & \\
\hline 0 & 30.100 & 186.732 & -184.412 & & & & \\
\hline 0 & 40.200 & 186.732 & 0.000 & & & & \\
\hline 1081263 & 113.466 & 544.766 & 5639.294 & & & & \\
\hline 6126.66 & 186.732 & 912.900 & 5693.028 & & & & \\
\hline 16939.29 & 10.000 & 186.732 & 10961.909 & & & & \\
\hline
\end{tabular}




\subsection{Strength Analysis of Bridge Beam Box}

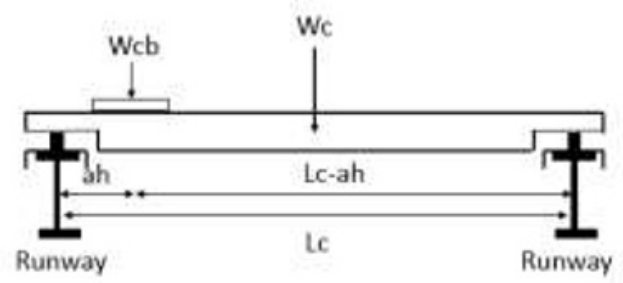

Fig. 4: Bridge Crane.

In processing, the finite element method with the solid work simulation program was employed in the 8 following main steps:

(1) Check the integrity of the CAD file

(2) Define the boundary conditions of the grip and support the actual working conditions.

(3) Determine the force load to determine both position and size. The value derived from the calculation.
(4) Specify the type of material as standard iron steel with BS: 5950: 2000 grade 460.

(5) Determine the type and shape of the elements that are appropriate for the complex structure work.

(6) Create mesh especially using the fine mesh in the complex structure area.

(7) Use the workpiece command and then the obtained results is analyzed for the accuracy.

\section{Results and Discussion}

\subsection{Result of Design Analysis of Runway Overhead Crane}

The results obtained from the calculation of the overhead crane design were shown in Table 6. Fig. 5-6 showed the position of the analysis. Fig. 7-10 showed the maximum bending moment. The forces acting on the support points were shown in Fig. 11-12.

Table 6. Result of Design Analysis

\begin{tabular}{|c|c|c|c|}
\hline \multicolumn{4}{|c|}{ Maximum Vertical Moments } \\
\hline Distances & $\mathrm{a}=2 \mathrm{~m}$ & $\mathrm{~S}=4 \mathrm{~m}$ & $\mathrm{C}=4 \mathrm{~m}$ \\
\hline Due to Dead Load & $\mathrm{R}_{\mathrm{a}}=6 \mathrm{kN}$ & $\mathrm{R}_{\mathrm{b}}=6 \mathrm{kN}$ & $\mathrm{M}=14.4 \mathrm{kNm}$ \\
\hline Due to Crane Load & $\mathrm{R}_{\mathrm{a}}=208 \mathrm{kN}$ & $\mathrm{R}_{\mathrm{b}}=138 \mathrm{kN}$ & $\mathrm{M}=554.7 \mathrm{kNm}$ \\
\hline \multicolumn{3}{|c|}{ Momement Mx1 = 1.4 Dead Load + 1.6 Crane Load with Impact } & $\mathrm{M}=907.7 \mathrm{kNm}$ \\
\hline Momement Mx2 = $1.4 \mathrm{I}$ & $\mathrm{oad}+1.4 \mathrm{Cra}$ & mpact & $\mathrm{M}=796.7 \mathrm{kNm}$ \\
\hline \multicolumn{4}{|c|}{ Maximum Horizontal Moments } \\
\hline Due to Crane Surge & $\mathrm{R}_{\mathrm{a}}=6.5 \mathrm{kN}$ & $\mathrm{R}_{\mathrm{b}}=4.3 \mathrm{kN}$ & $\mathrm{M}=17.2 \mathrm{kNm}$ \\
\hline \multicolumn{3}{|c|}{ Moment My = 1.4 Crane Load due to Surge } & $\mathrm{M}=24.1 \mathrm{kNm}$ \\
\hline \multirow{2}{*}{\multicolumn{4}{|c|}{$\begin{array}{l}\text { Due to Crane Crabbing } \\
\text { Vertical Deflection Check }\end{array}$}} \\
\hline & & & \\
\hline Distances & $a=3 m$ & $\mathrm{~S}=4 \mathrm{~m}$ & $\mathrm{C}=3 \mathrm{~m}$ \\
\hline \multicolumn{3}{|l|}{ Max Actual Deflection } & $4.96 \mathrm{~mm}$ \\
\hline \multirow{2}{*}{\multicolumn{3}{|c|}{$\begin{array}{l}\text { Permit Deflection } \\
\text { Horizontal Deflection Check }\end{array}$}} & $16.67 \mathrm{~mm}$ \\
\hline & \multicolumn{3}{|c|}{ Horizontal Deflection Check } \\
\hline Distances & $a=3 m$ & $\mathrm{~S}=4 \mathrm{~m}$ & $\mathrm{C}=3 \mathrm{~m}$ \\
\hline \multicolumn{3}{|l|}{ Surge Deflection } & $6.99 \mathrm{~mm}$ \\
\hline \multicolumn{3}{|l|}{ Crabbing Deflection } & $16.62 \mathrm{~mm}$ \\
\hline \multicolumn{3}{|l|}{ Max Actual Deflection } & $16.62 \mathrm{~mm}$ \\
\hline \multicolumn{3}{|c|}{ Permit Deflection } & $20.00 \mathrm{~mm}$ \\
\hline \multicolumn{4}{|c|}{ Shear, Bending, Compression Check } \\
\hline \multicolumn{3}{|l|}{ Shear } & $3599.7 \mathrm{kN}$ \\
\hline \multicolumn{3}{|c|}{ Shear Ratio 0.126} & 452.16 \\
\hline \multicolumn{3}{|c|}{ Bending (1.4 Dead Load + 1.6 Vertical Crane Load) } & 0.483 \\
\hline \multirow{2}{*}{\multicolumn{3}{|c|}{ Maximum Bending 1.4 (Dead Load + Vertical Crane Load + Horizontal Crabbing) }} & 0.703 \\
\hline & & & $101.8 \mathrm{~N} / \mathrm{mm}^{2}$ \\
\hline
\end{tabular}




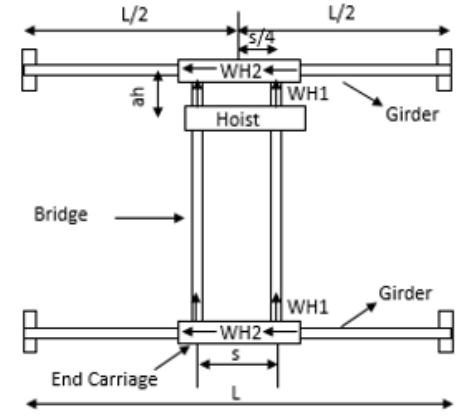

Fig. 5: Crane layout $\&$ transverse surge force for maximum horizontal moment

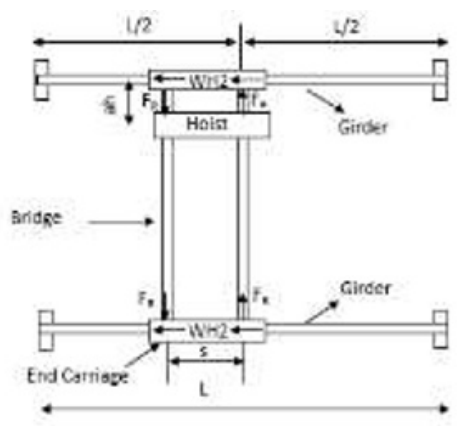

Fig. 6: Crane layout \& crabbing forces for maximum horizontal moment

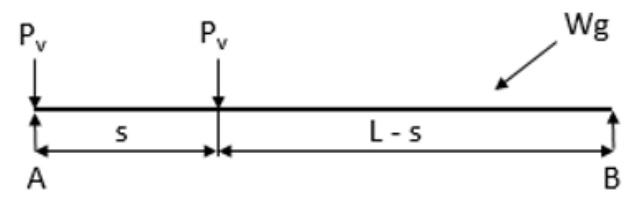

Fig. 7: Vertical Load Positions Causing Maximum Vertical Shear

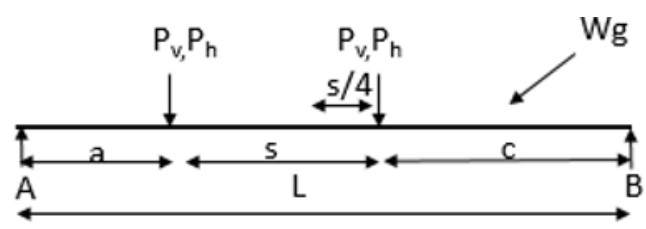

Fig. 8: Load Positions Causing Maximum Vertical \& Horizontal Moment

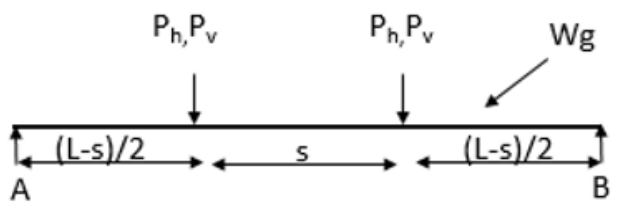

Fig. 9: Load Positions Causing Maximum Vertical \& Horizontal Deflection

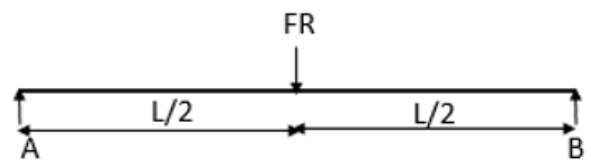

Fig. 10: Crabbing Load Position Causing Maximum Horizontal Moment \& Deflection

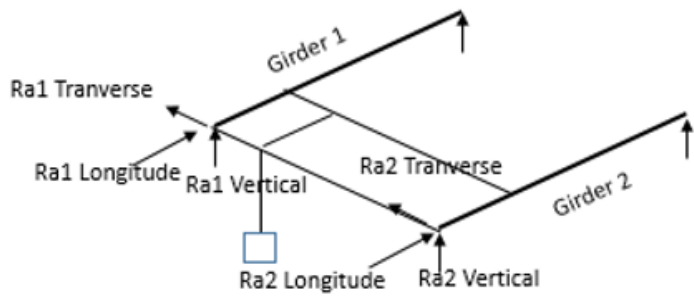

Fig. 11: Reactions on to the Support Structure with Crane Crabbing

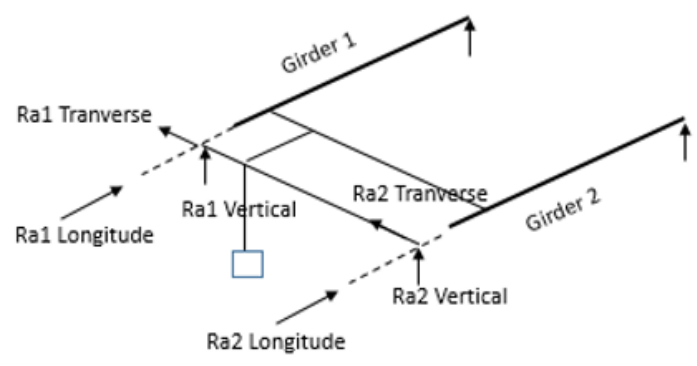

Fig. 12: Reactions on to the Support Structure with Crane Crabbing

\subsection{Results of Strength Analysis of Bridge Beam Box}

The stress analysis of the beams with finite element method [1-14] is shown in Fig. 13. The maximum stress of $338 \mathrm{MPa}$ gives a safety value of 1.83 .

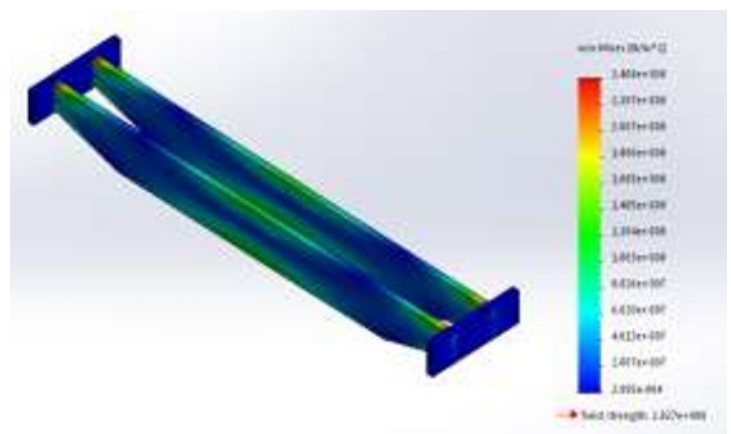

Fig.13: Result of Stress Analysis. 


\section{Summary}

Crane design analysis, which satisfies ASME B30.22005 standards, is highly accurate and reliable. Therefore, the cost of construction can be reduced to 1.83., and provides 20 tons of cranes as desired. It is suitable for use within designated areas. The data of this design will be employed to construct the overhead crane of the local fishing boat maintenance workshop.

\section{References}

1. Haniszewski T., Strength analysis of overhead traveling crane with use of finite element method, J trans Prob. Vol. 9(1) (2014), p. 1926.

2. Pratik R, Patel V.K., A review on structural analysis of overhead crane girder using FEA technique, Int. j. innov. res. sci. eng technol. Vol. 2(4) (2013), p. 41-44.

3. Alkin C, Imrak C.E, Kocabas H.J., Solid modeling and finite element analysis of an overhead crane bridge, Acta Polytech. Vol. 45(3) (2005), p. 61-67.

4. Sankar V.V, Vijayan P. Ashraf M.Y., Reducing the structural mass of a real-world double girder overhead crane, Int. j. adv. eng. technol. Vol. 8(2) (2015), p. 150-162.

5. Yifei T, Wei Y, Zhen Y, Dongbo L, Xiangdong L., Research on multidisciplinary optimization design of bridge crane, Math. probl. eng. (2013), p. 1-10.

6. Khalidurfeasif P, Bharti D., Finite element analysis of $450 \mathrm{t}$ eot crane box girder, Int. j. adv. eng. res. dev. Vol. 2(11) (2015), p. 171178.

7. Kapadni R, Ganiger S.G., A review paper on design and structural analysis of simply supported gantry crane beam for eccentric loading, Int. res. j. eng. Technol. Vol. 2(8) (2015), p. 1622-1626.

8. Vlada G, Mllorad M, Zoran., FEA Implementation in moving load problem at bridgr cranes, Mach des. (2010), p. 25-30.

9. Vankatesh A, Vignesh S, Iyappan S, Kumar P, Tamilvanan G, Sarathy R., Design of an over head plate gantry girder, Int. j. dev. Res. Vol. 5(6) (2016), p. 7821-7823.

10. Patel K, Jani V.K., J. inf. knowl. Design and dynamic analysis of $70 \mathrm{t}$ double girder electrical overhead crane, Res. mech. eng. Vol. 2(2) (2013), p. 496-503.

11. Nenad M, Rodolju., Analysis of overhead travelling crane's motion in horizontal plane, Int. j. eng. (2016), p. 21-24.

12. Bhutta M, Misbahuddin M, Qureshi M, Ahmad S, Mughal H., Using finite element analysis for design optimization of twin beam crane arm, Sci. int. Vol. 28(1) (2016), p. 131-138.
13. Sitthipong S, Muangjunburee P, Detchvayukul, Totarat N, Stress analysis of swing shaft in the transmission system of electric shovel, Naresuan Phayao J. Vol. 9(4) (2016), p. 21-24.

14. Sitthipong $\mathrm{S}$, Muangjunburee $\mathrm{P}$, Detchvayukul, Totarat N., Stress Analysis of Final Drive Pinion Shaft of Electric Shovel Through The Use of FEM, Thaksin. Uni. J. Vol. 20(1) (2017), p. 57-66. 